\title{
Intermittent Aeration Suppresses Nitrite-Oxidizing Bacteria in Membrane-Aerated Biofilms: A Model-Based Explanation
}

Ma, Yunjie; Domingo Felez, Carlos; Plósz, Benedek G.; Smets, Barth F.

\section{Published in:}

Environmental Science and Technology

Link to article, DOI:

10.1021/acs.est.7b00463

Publication date:

2017

Document Version

Peer reviewed version

Link back to DTU Orbit

Citation (APA):

Ma, Y., Domingo Felez, C., Plósz, B. G., \& Smets, B. F. (2017). Intermittent Aeration Suppresses NitriteOxidizing Bacteria in Membrane-Aerated Biofilms: A Model-Based Explanation. Environmental Science and Technology, 51(11), 6146-6155. https://doi.org/10.1021/acs.est.7b00463

\section{General rights}

Copyright and moral rights for the publications made accessible in the public portal are retained by the authors and/or other copyright owners and it is a condition of accessing publications that users recognise and abide by the legal requirements associated with these rights.

- Users may download and print one copy of any publication from the public portal for the purpose of private study or research.

- You may not further distribute the material or use it for any profit-making activity or commercial gain

- You may freely distribute the URL identifying the publication in the public portal 


\title{
1 Suppression of Nitrite-Oxidizing Bacteria in Intermittently 2 Membrane-Aerated Biofilms: A Model-Based Explanation
}

\author{
3 Yunjie Ma, Carlos Domingo-Félez, Benedek Gy. Plósz, ${ }^{\dagger}$ and Barth F. Smets*i) \\ 4 Department of Environmental Engineering, Technical University of Denmark, Miljøvej Building 113, 2800 Kongens Lyngby, \\ 5 Denmark
}

6 S Supporting Information

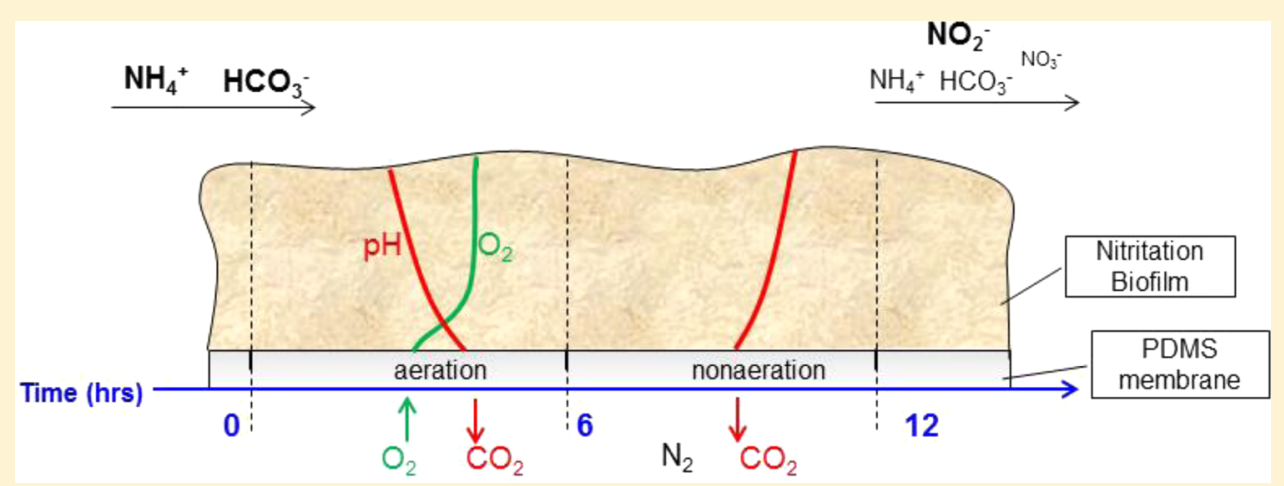

7 ABSTRACT: Autotrophic ammonium oxidation in membrane-aerated biofilm reactors (MABRs) can make treatment of ammonium-rich wastewaters more energy-efficient, especially within the context of short-cut ammonium removal. The challenge is to exclusively enrich ammonium-oxidizing bacteria (AOB). To achieve nitritation, strategies to suppress nitrite-oxidizing bacteria (NOB) are needed, which are ideally grounded on an understanding of underlying mechanisms. In this study, a counterdiffusion nitrifying biofilm reactor was operated under intermittent aeration. During eight months of operation, AOB dominated, while NOB were suppressed. On the basis of dissolved oxygen (DO), ammonium, nitrite, and nitrate profiles within the biofilm and in the bulk, a 1-dimensional nitrifying biofilm model was developed and calibrated. The model was utilized to explore the potential mechanisms of NOB suppression associated with intermittent aeration, considering DO limitation, direct $\mathrm{pH}$ effects on enzymatic activities, and indirect $\mathrm{pH}$ effects on activity via substrate speciation. The model predicted strong periodic shifts in the spatial gradients of $\mathrm{DO}, \mathrm{pH}$, free ammonia, and free nitrous acid, associated with aerated and nonaerated phases. NOB suppression during intermittent aeration was mostly explained by periodic inhibition caused by free ammonia due to transient periodic $\mathrm{pH}$ upshifts. Dissolved oxygen limitation did not govern NOB suppression. Different intermittent aeration strategies were then evaluated for nitritation success in intermittently aerated MABRs: both aeration intermittency and duration were effective control parameters.

\section{INTRODUCTION}

21 Short-cut ammonium $\left(\mathrm{NH}_{4}^{+}\right)$removal via nitrite $\left(\mathrm{NO}_{2}^{-}\right)$is 22 more energy- and cost-efficient than traditional $\mathrm{NH}_{4}^{+}$removal 23 via nitrate $\left(\mathrm{NO}_{3}{ }^{-}\right)$due to reduced aeration and external 24 electron donor requirements. ${ }^{1-3}$ This process requires full 25 nitritation (oxidation of all $\mathrm{NH}_{4}^{+}$to $\mathrm{NO}_{2}^{-}$) and zero nitratation 26 (oxidation of none of the $\mathrm{NO}_{2}{ }^{-}$to $\mathrm{NO}_{3}{ }^{-}$): in other words, 27 minimal activity of nitrite-oxidizing bacteria (NOB) and 28 maximal activity of ammonium-oxidizing bacteria (AOB). 29 Similar conditions, with only partial nitritation, can also be 30 exploited to convert $\mathrm{NH}_{4}^{+}$to a 50:50 mixture of $\mathrm{NO}_{2}^{-}$and $31 \mathrm{NH}_{4}^{+}$, which can then be coupled to anoxic $\mathrm{NH}_{4}^{+}$oxidation to 32 attain even more resource efficient ammonium removal., ${ }^{4,5}$

33 Various conditions have been successfully tested to suppress $34 \mathrm{NOB}$ over $\mathrm{AOB}$ activity or wash-out NOB over AOB biomass 35 to attain nitritation in suspended growth systems. They include 36 the operation of bioreactors at limited dissolved oxygen (DO) 37 concentrations, ${ }^{6}$ at high temperature combined with low solids retention times, ${ }^{1}$ and at elevated free ammonia (FA) and/or 38 free nitrous acid (FNA) concentrations. ${ }^{7}$ In all cases, NOB 39 suppression or outcompetition versus $\mathrm{AOB}$ is based on 40 differential growth kinetics. Sometimes, the proper choice of 41 system inoculum also accelerates AOB over NOB selection. ${ }^{8}$ In 42 contrast, maintaining long-term nitritation in biofilm-based 43 reactors can be more challenging ${ }^{9}$ due to long solids retention 44 times in biofilms that interfere with outcompetition based on 45 kinetic principles. Finding operational conditions and confirm- 46 ing mechanisms that suppress $\mathrm{NOB}$ in biofilms remain a 47 challenge. On the one hand, the existence of strong spatial 48 chemical gradients (e.g., of DO, pH, and nitrogenous species) 49 in nitrifying biofilms ${ }^{10}$ makes it difficult to prescribe environ- 50

Received: January 24, 2017

Revised: April 26, 2017

Accepted: April 27, 2017

Published: April 27, 2017 
51 mental conditions that favor AOB over NOB in the system. On 52 the other hand, the existence of multiple simultaneous chemical 53 gradients complicates identification of the underlying mecha54 nism(s) that suppresses NOB. For example, $\mathrm{pH}$ and $\mathrm{DO}$ 55 gradients occur simultaneously in active nitrifying biofilms: ${ }^{11}$ it 56 is difficult to unravel to what extent nitritation failure or success 57 is associated with the differential effect of oxygen (AOB and 58 NOB having different oxygen affinities $)^{12}$ or the differential 59 effects of $\mathrm{pH}$ ( $\mathrm{AOB}$ and $\mathrm{NOB}$ responding differently to $\mathrm{pH}$, as 60 a consequence of the $\mathrm{pH}$-dependent maximum growth 61 rates $^{13,14}$ and the $\mathrm{pH}$-dependent speciation of FA and FNA 62 which act as both substrates and inhibitors).

63 Mathematical models are one way to describe multiple 64 processes that occur simultaneously in time and space in 65 nitrifying biofilms. ${ }^{15,16}$ A multispecies nitrifying biofilm model 66 (MSNBM) was explicitly developed to study the competition 67 between $\mathrm{AOB}$ and NOB; effects of $\mathrm{DO}, \mathrm{pH}, \mathrm{FA}$, and FNA on 68 growth kinetics were incorporated in a spatially explicit way to 69 evaluate operational conditions for NOB suppression in 70 codiffusion biofilms. ${ }^{3,17}$ Park et al. ${ }^{17}$ showed that FA inhibition 71 of NOB was more efficient in nascent biofilms (when residual $72 \mathrm{NH}_{4}^{+}$was still high), but that DO limitation was the dominant 73 mechanism of NOB suppression in established biofilms. 74 Besides bulk DO and influent $\mathrm{NH}_{4}{ }^{+}$concentration, the model 75 suggested that bulk buffer capacity was another means to 76 manipulate $\mathrm{NOB}$ suppression by affecting $\mathrm{pH}$ gradients within 77 biofilms.

78 While $\mathrm{AOB} / \mathrm{NOB}$ competition in conventional codiffusion 79 biofilms has been studied in some detail, ${ }^{3,17,18}$ there are less 80 studies on $\mathrm{AOB} / \mathrm{NOB}$ competition in the context of nitritation 81 in counter-diffusion biofilms. Counter-diffusion biofilms 82 develop in membrane-aerated biofilm reactors (MABRs), 83 where air delivery is via the biofilm base. ${ }^{19}$ MABRs have 84 been broadly explored for autotrophic $\mathrm{N}$ removal. ${ }^{1,20,21}$ In 85 counter-diffusion nitrifying MABRs, active bacteria thrive at the 86 base of the biofilm, where they utilize oxygen supplied from the 87 membrane lumen. Growth of bacteria, including NOB, at the 88 biofilm base would limit the chance for outcompetition, once 89 established, due to spatial protection by the overlying biofilm 90 layers. Efficient operation of MABRs to attain long-term 91 nitritation has, to our knowledge, not been documented, with 92 the exception of one, highly loaded ( $33 \mathrm{~g}-\mathrm{N} / \mathrm{m}^{2} /$ day), fully $93 \mathrm{NH}_{4}^{+}$penetrated MABR where controlling DO concentrations 94 at the membrane-biofilm interface sufficed to maintain 95 nitritation. $^{22}$

96 Recently, Pellicer-Nàcher et al. $^{21}$ observed that fully 97 nitratated MABRs accumulated $\mathrm{NO}_{2}{ }^{-}$immediately after 98 switching from continuous to intermittent aeration, even at 99 elevated oxygen loadings. The causal link between nitritation 100 onset and aeration regime change was not explored. Here, we 101 report additional experimental evidence of NOB suppression in 102 intermittently aerated MABRs and we develop and calibrate an 103 improved MSNBM incorporating explicit $\mathrm{pH}$ calculation. Using 104 the calibrated model, we systematically evaluate potential 105 causes for NOB suppression associated with intermittent 106 aeration. From this analysis, we identify the periodic FA 107 inhibition, caused by transient $\mathrm{pH}$ upshifts and decreases at the 108 biofilm base, as the likely key cause for NOB suppression. A 109 suitable operational window for an effective nitritation control 110 in counter-diffusion systems is finally proposed.

\section{MATERIALS AND METHODS}

2.1. Reactor Operation and Measurement Methods. 111 2.1.1. Reactor Configuration and Operation. The counter- 112 diffusion MABRs consisted of two tubular gas filled PDMS 113 membranes (3100506, Labmarket, Germany), both fixed in 114 parallel to their longer dimension (Figure S1). The system had 115 a liquid volume of $0.83 \mathrm{~L}$ (reactors: $31.5 \times 5 \times 3.5 \mathrm{~cm}$ ) and was 116 inoculated with enriched nitrifying biomass. ${ }^{21}$ To start up the 117 system, the reactor was first run in a batch mode with an initial 118 $\mathrm{NH}_{4}{ }^{+}$concentration at $300 \mathrm{mg}-\mathrm{N} / \mathrm{L}$ and continuous aeration. 119 The onset of $\mathrm{NH}_{4}^{+}$consumption without oxygen accumulation 120 in the bulk suggested biomass attachment around the 121 membranes. Subsequently, the MABR was operated in 122 continuous flow mode under intermittent aeration. Synthetic 123 wastewater was fed continuously with an $\mathrm{NH}_{4}{ }^{+}$concentration 124 at $75 \mathrm{mg}-\mathrm{N} / \mathrm{L}$ and without external organic carbon. Hydraulic 125 retention time was $12 \mathrm{~h}$. The intermittent aeration strategy 126 consisted of a $6 \mathrm{~h}$ aeration period (100\% air) followed by a $6 \mathrm{~h} 127$ nonaeration period $\left(100 \% \mathrm{~N}_{2}\right)$. The aeration cycles were 128 controlled by a set of solenoid valves, and the pressure in the 129 lumen was $35 \mathrm{kPa}$. The bulk phase was completely mixed by 130 recirculating at $1.5 \mathrm{~L} / \mathrm{min}$. $\mathrm{DO}$ and $\mathrm{pH}$ were measured with 131 electrodes in the recirculation line (CellOX 325 and Sentix 41, 132 WTW, Germany). Bulk pH was not controlled and remained at 133 $7.2 \pm 0.2$ due to adequate buffer capacity (molar ratio in the 134 influent: $\mathrm{HCO}_{3}{ }^{-} / \mathrm{NH}_{4}{ }^{+}=2.1$ ). Reactor temperature was at 32.5135 $\pm 0.7{ }^{\circ} \mathrm{C}$, which was above ambient temperature due to the 136 unintentional heat added by the recirculation pump. The 137 working temperature was not controlled to a lower value, as 138 temperature effect on nitritation success in MABRs is 139 minor. ${ }^{23,24} \mathrm{~N}$ concentrations $\left(\mathrm{NH}_{4}^{+}, \mathrm{NO}_{2}{ }^{-}\right.$, and $\left.\mathrm{NO}_{3}{ }^{-}\right)$were 140 measured with colorimetric test kits (Spectroquant 14776, 141 00683, 09713; Merck, Germany).

142

2.1.2. Microelectrode Measurements. Commercially avail- 143 able DO microelectrode (OX-10, Unisense, Denmark) and lab- 144 made potentiometric microelectrodes for $\mathrm{NH}_{4}^{+}, \mathrm{NO}_{2}^{-}$, and 145 $\mathrm{NO}_{3}{ }^{-25}$ were used for in situ profiling measurements within the 146 biofilm. Profiling measurements were performed after biofilms 147 reached steady state. Microelectrodes were controlled by a 148 motorized micromanipulator to a precision up to $10 \mu \mathrm{m}$ and 149 began from the top of the biofilm. During measurements, the 150 influent and recirculation were kept unchanged. For each 151 profile, replicates $(n>3)$ were made and the average was 152 considered in model fitting. Besides calibration following the 153 protocols, the signal drift of $\mathrm{N}$-species sensors over time was 154 corrected by measuring $\mathrm{N}$ concentrations from effluent before 155 and after profiling.

2.2. Model Development. The MSNBM is a one- 157 dimensional model based on Terada et al., ${ }^{26}$ incorporating 158 additional explicit $\mathrm{pH}$ calculation (Table S1). It was 159 implemented in AQUASIM V2.1 with two compartments: a 160 completely mixed gas compartment and a biofilm compartment 161 containing biofilm and bulk liquid. ${ }^{27}$ In the counter-diffusion 162 regime, a physical diffusion link connects the gas compartment 163 to the base of the biofilm, defined as

$$
A \times k_{\mathrm{M}, \mathrm{i}}\left(\frac{1}{H_{\mathrm{i}}} C_{\mathrm{i}, \text { air }}-C_{\mathrm{i}, \text { base }}\right)
$$

where $C_{\mathrm{i}, \text { air }}$ and $C_{\mathrm{i} \text {,base }}$ are concentrations of carbon dioxide 166 $\left(\mathrm{CO}_{2}\right)$ or oxygen $\left(\mathrm{O}_{2}\right)$ in the gas compartment and at the 167 biofilm base $(\mathrm{mg} / \mathrm{L}), H$ is the nondimensional Henry's Law 168 coefficient $\left(1.32\right.$ for $\mathrm{CO}_{2}, 34.55$ for $\left.\mathrm{O}_{2}, 33{ }^{\circ} \mathrm{C}\right)$, and $k_{\mathrm{M}, \mathrm{i}}$ is the 169 
170 silicone membrane gas mass transfer coefficient $\left(k_{{\mathrm{M}, \mathrm{O}_{2}}_{2}}=6 \mathrm{~m} / \mathrm{d}\right.$, ${ }_{171} k_{\mathrm{M}, \mathrm{CO}_{2}}=0.8 \mathrm{~m} / \mathrm{d}$, Table S3). Gas transfer of $\mathrm{N}_{2}$ and $\mathrm{NH}_{3}$ is not 172 modeled. Other major modeling assumptions, regarding biofilm 173 structure, diffusion mass transfer, and boundary layer thickness, 174 are as in Terada et al. ${ }^{26}$ Process rate expressions are shown in 175 Table S2. The calibrated nitrification model incorporating $\mathrm{pH}$ is 176 available from the corresponding author.

177 2.2.1. Biological Processes. The MSNBM includes 3 active 178 microbial groups, $\mathrm{AOB}, \mathrm{NOB}$, and heterotrophs (HB), and 179 inerts accumulated during decay processes. For the two-step 180 nitrification process, FA and FNA are considered as true 181 substrates for growth and inhibition in nitritation and 182 nitratation. $^{28}$ The growth rate expressions are described as 183 follows,

$$
\begin{aligned}
& \text { AOB: } \mu_{\mathrm{AOB}} \times X_{\mathrm{AOB}} \times \frac{S_{\mathrm{O}_{2}}}{K_{\mathrm{O}_{2}}^{\mathrm{AOB}}+S_{\mathrm{O}_{2}}} \\
& \times \frac{S_{\mathrm{FA}}}{K_{\mathrm{FA}}^{\mathrm{AOB}}+S_{\mathrm{FA}}+S_{\mathrm{FA}} \times S_{\mathrm{FA}} / K_{\mathrm{I}, \mathrm{FA}}^{\mathrm{AOB}}} \times \frac{K_{\mathrm{I}, \mathrm{FNA}}^{\mathrm{AOB}}}{K_{\mathrm{I}, \mathrm{FNA}}^{\mathrm{AOB}}+S_{\mathrm{FNA}}}
\end{aligned}
$$

184

$$
\begin{aligned}
& \text { NOB: } \mu_{\mathrm{NOB}} \times X_{\mathrm{NOB}} \times \frac{S_{\mathrm{O}_{2}}}{K_{\mathrm{O}_{2}}^{\mathrm{NOB}}+S_{\mathrm{O}_{2}}} \\
& \times \frac{S_{\mathrm{FNA}}}{K_{\mathrm{FNA}}^{\mathrm{NOB}}+S_{\mathrm{FNA}}+S_{\mathrm{FNA}} \times S_{\mathrm{FNA}} / K_{\mathrm{I}, \mathrm{FNA}}^{\mathrm{NOB}}} \times \frac{K_{\mathrm{I}, \mathrm{FA}}^{\mathrm{NOB}}}{K_{\mathrm{I}, \mathrm{FA}}^{\mathrm{NOB}}+S_{\mathrm{FA}}}
\end{aligned}
$$

185

186 where $\mu$ is the specific growth rate coefficient (1/day), ${ }_{187}$ dependent on local $\mathrm{pH}$ and $\mu_{\mathrm{max}} ; S_{\mathrm{O}_{2}}, S_{\mathrm{FA}}$ and $S_{\mathrm{FNA}}$ are $\mathrm{O}_{2}$, ${ }_{188} \mathrm{FA}$, and FNA concentrations $(\mathrm{mg} / \mathrm{L})$, respectively; $K_{\mathrm{O}_{2}}, K_{\mathrm{FA}}$, 189 and $K_{\mathrm{FNA}}$ are half-saturation coefficients $(\mathrm{mg} / \mathrm{L}) ; K_{\mathrm{I}, \mathrm{FA}}$ and $190 K_{\mathrm{I}, \mathrm{FNA}}$ are inhibition coefficients $(\mathrm{mg} / \mathrm{L})$. Growth substrate 191 inhibition (FA for AOB, FNA for NOB) is incorporated with 192 the Andrews equation. Other types of inhibition (FA for NOB, 193 FNA for AOB) are described with a noncompetitive inhibition 194 term, as routinely done in similar studies. ${ }^{28,29}$

195 For the denitrification process, $\mathrm{NO}_{2}{ }^{-}$and $\mathrm{NO}_{3}{ }^{-}$are modeled 196 as separate electron acceptors. To avoid unnecessary complex197 ity and focus on AOB/NOB competition, no intermediates 198 ( $\mathrm{NO}$ or $\mathrm{N}_{2} \mathrm{O}$ ) are considered. Bacteria have different decay 199 rates in aeration and nonaeration periods: to simplify the 200 model, AOB/NOB are assumed not to decay under anoxic or 201 anaerobic conditions; ${ }^{30}$ meanwhile, HB decay is modified by an 202 anoxic reduction factor during nonaeration periods.

203 2.2.2. Chemical Process: $\mathrm{pH}$ Calculation. The one-dimen204 sional model can keep track of local $\mathrm{pH}$ changes perpendicular 205 to the membrane substratum. $\mathrm{pH}$ along biofilm depth is 206 calculated on the basis of the proton production via nitrification 207 and consumption via denitrification, the equilibrium reaction 208 with bicarbonate buffer, and $\mathrm{CO}_{2}$ stripping to the membrane 209 lumen. The consumption of inorganic carbon for autotrophic 210 growth is neglected as it has insignificant influence on $\mathrm{pH}$ 211 changes under conditions when inorganic carbon is not 212 limiting.

213 Protons produced and consumed in bioprocesses are listed in 214 the stoichiometry matrix. The acid-base balance reaction with 215 bicarbonate buffer is assumed to occur much faster than 216 biological processes. ${ }^{31}$

$$
\mathrm{H}^{+}+\mathrm{HCO}_{3}^{-} \leftrightarrow \mathrm{H}_{2} \mathrm{CO}_{3}\left(\mathrm{CO}_{2}\right) \quad \text { rate: }\left(\frac{S_{\mathrm{HCO}_{3}^{-}} \times S_{\mathrm{H}}}{K_{\mathrm{a}, \mathrm{HCO}_{3}}}-S_{\mathrm{CO}_{2}}\right) \times 10^{7}
$$

where $S_{\mathrm{H}}, S_{\mathrm{HCO}_{3}}^{-}$, and $S_{\mathrm{H}_{2} \mathrm{CO}_{3}\left(\mathrm{CO}_{2}\right)}$ are concentrations of proton, 218 bicarbonate, and the sum of carbonic acid and dissolved carbon 219 dioxide, respectively $(\mu \mathrm{mol} / \mathrm{L}) ; K_{\mathrm{a}, \mathrm{HCO}_{3}}$ is the dissociation 220 equilibrium constant of carbonic acid $\left(0.574 \mu \mathrm{mol} / \mathrm{L}, 33{ }^{\circ} \mathrm{C}, 1221\right.$ $\mathrm{atm})$. Protons produced in the nitritation process titrate 222 $\mathrm{HCO}_{3}{ }^{-}$to $\mathrm{H}_{2} \mathrm{CO}_{3}$, and oversaturated $\mathrm{CO}_{2}$ diffuses from the 223 biofilm base to the membrane lumen (eq 1). Acid-base 224 reactions with phosphate ions were minor and neglected, as the 225 molar ratio of $\mathrm{H}_{2} \mathrm{PO}_{4}{ }^{-} / \mathrm{HCO}_{3}{ }^{-}$in influent was lower than $3 \% .226$

2.2.3. Limitations/Inhibitions of $A O B / N O B$ Activity. The 227 growth rate expressions of $\mathrm{AOB}$ and $\mathrm{NOB}$ consider DO and 228 $\mathrm{pH}$ effects. DO limitation is assessed by oxygen affinity 229 constants. Two $\mathrm{pH}$ effects are included. (1) pH-enzyme effect: 230 $\mathrm{pH}$ can affect nitrifying activity directly by changing the enzyme 231 reaction mechanism or increasing the demand for maintenance 232 energy. $^{31,32}$ A Gaussian bell-shaped curve is chosen to model 233 the $\mathrm{pH}$-enzyme dependency of specific growth rates. ${ }^{13}$

234

$$
\mu=\frac{\mu_{\max }}{2}\left\{1+\cos \left[\frac{\pi}{\omega} \times\left(\mathrm{pH}-\mathrm{pH}_{\mathrm{opt}}\right)\right]\right\} \quad\left|\mathrm{pH}-\mathrm{pH}_{\mathrm{opt}}\right|<\omega
$$

where $\mu_{\max }$ is the maximum specific growth rate at the optimal 236 $\mathrm{pH}, \mathrm{pH}_{\mathrm{opt}}$ and $\omega$ is the $\mathrm{pH}$ range within which $\mu$ is larger than 237 a half of $\mu_{\max }$; (2) $\mathrm{pH}$ substrate-speciation effect: local $\mathrm{pH} 238$ values determine FA/FNA speciation from total $\mathrm{NH}_{4}^{+} / \mathrm{NO}_{2}{ }^{-} \cdot 239$ The speciation between ionized/un-ionized species is assumed 240 at instantaneous equilibrium. ${ }^{33}$

$$
S_{\mathrm{FA}}=\frac{K_{a, \mathrm{NH}_{3}} \times S_{\mathrm{NH}_{4}}}{S_{\mathrm{H}}} \quad S_{\mathrm{FNA}}=\frac{S_{\mathrm{NO}_{2}} \times S_{\mathrm{H}}}{K_{a, \mathrm{NO}_{2}}}
$$

where $K_{\mathrm{a}, \mathrm{NH}_{3}}$ and $K_{\mathrm{a}, \mathrm{NO}_{2}}$ are dissociation equilibrium constants 243 of ammonium and nitrous acid, respectively (0.000794 and 244 $\left.628.96 \mu \mathrm{mol} / \mathrm{L}\left(33^{\circ} \mathrm{C}, 1 \mathrm{~atm}\right)\right)$. Substrate speciation will result 245 in differential degrees of FA/FNA inhibition.

2.3. Sensitivity Analysis and Parameter Estimation. To 247 investigate the most determinant parameters on reactor 248 performance, a sensitivity analysis was performed. Initial values 249 of kinetic parameters were taken from the ASMN model. ${ }^{28}$ The 250 optimal $\mathrm{pH}$ ranges for $\mathrm{AOB}$ and $\mathrm{NOB}$ growth kinetics $\left(\mathrm{pH}_{\mathrm{opt}} 251\right.$ and $\omega$ ) were from Park et al. ${ }^{13}$ The temperature correction for 252 $\mu_{\max }$ and $b_{\max }$ are from Hao et al. ${ }^{34}$ The MSNBM was first run 253 in continuous aeration with default values for 300 days to 254 achieve a stable nitrifying biofilm. Then, a local sensitivity 255 analysis was performed after switching to intermittent aeration, 256 giving the individual parameter a $100 \%$ value change while all 257 others remained constant. ${ }^{27}$ Reactor performances were 258 evaluated in terms of ammonium removal efficiency (ARE, 259 $\left.\frac{S_{\mathrm{NH}_{4}, \text { in }}-S_{\mathrm{NH}_{4}, \text { eff }}}{S_{\mathrm{NH}_{4}, \text { in }}} \%\right)$, nitrate production efficiency $(\mathrm{NaE}$, $\left.\frac{S_{\mathrm{NO}_{3}, \text { eff }}}{S_{\mathrm{NH}_{4}, \text { in }}-S_{\mathrm{NH}_{4}, \text { eff }}} \%\right)$, nitritation efficiency (NE, $\left.\frac{S_{\mathrm{NO}_{2}, \text { eff }}}{S_{\mathrm{NH}_{4}, \text { in }}-S_{\mathrm{NH}_{4}, \text { eff }}} \%\right)$ and $\mathrm{NOB}$ fraction (fNOB, $\frac{\mathrm{NOB}}{\mathrm{NOB}+\mathrm{AOB}} \%$ ). The normalized 260 sensitivity function is defined as,

$$
\delta_{\mathrm{j}}=\sqrt{\operatorname{average}\left(\operatorname{Sens}_{\mathrm{i}, \mathrm{j}}{ }^{2}\right)} \text { and Sens } \mathrm{i}_{\mathrm{j}, \mathrm{j}}=p_{\mathrm{i}, \mathrm{j}} \frac{\Delta y_{\mathrm{j}}}{\Delta p_{\mathrm{i}, \mathrm{j}}}
$$


263 where $\delta_{\mathrm{j}}, y_{\mathrm{j}}$, and $p_{\mathrm{i}, \mathrm{j}}$ are the sensitivity function, the output 264 reactor performances (ARE, $\mathrm{NaE}, \mathrm{NE}$, or $\mathrm{ANOB}$ ), and the input 265 parameters, respectively. Sens $\mathrm{i}_{\mathrm{i}, \mathrm{j}}$ was evaluated at different times 266 during the aeration cycles (time interval of 0.01 day) and at 20 267 equidistant points within the biofilm or 1 point in the bulk 268 phase. The averaged value was considered in the sensitivity 269 analysis, and parameter sensitivity was ranked for each targeted 270 performance metric. We focused on biokinetic and stoichio271 metric parameters related to $\mathrm{AOB}$ and $\mathrm{NOB}$, as $\mathrm{HB}$ parameters 272 are of secondary importance in nitrifying biofilms. ${ }^{35}$

273 The most sensitive parameters were calibrated with steady 274 state experimental data. The model calibration was carried out 275 by trial and error through adjusting the parameter values one by 276 one to minimize the fitting error. Root mean squared error was 277 used to assess the quality of model-data fit as the objective 278 function,

279

$$
\text { RMSE }=\sqrt{\operatorname{average}\left(\sum_{\mathrm{j}} \sum_{\mathrm{i}}\left(\frac{y_{\text {model }, \mathrm{i}, \mathrm{j}}-y_{\text {meas }, \mathrm{i}, \mathrm{j}}}{y_{\text {meas }, \mathrm{j}, \text { average }}}\right)^{2}\right)}
$$

280 where $\mathrm{j}$ is the targeted variable measured or estimated $\left(\mathrm{NH}_{4}{ }^{+}\right.$, $281 \mathrm{NO}_{2}{ }^{-}, \mathrm{NO}_{3}{ }^{-}$, and $\mathrm{DO}$ ) and $\mathrm{i}$ is a sample point along biofilm 282 depth $(i=20)$. The model was validated with additional 283 experimental data from this MABR and experimental data from 284 a separate membrane-aerated biofilm reactor (MABR2) 285 operated under 4 different ammonium surface loadings 286 (Table S5, detailed description of the experimental data used 287 in model calibration and validation). ${ }^{36}$ The calibrated 288 parameters were checked by comparing RMSE in the 289 calibration with RMSE in the validation and the Janus 290 coefficient $(J)$ was calculated, ${ }^{37}$

$$
J^{2}=\frac{\operatorname{RMSE}_{\mathrm{val}}^{2}}{\operatorname{RMSE}_{\mathrm{cal}}^{2}}
$$

292 2.4. Model Simulations. The calibrated MSNBM was run 293 in 3 scenarios (Table S6, detailed description of each simulation 294 scenario):

295 (1) To validate the model with extra experimental data, the

\section{RESULTS AND DISCUSSION}

314 3.1. Model Calibration and Evaluation. A sensitivity 315 function, considering the sum of reactor performances (ARE,
$\mathrm{NaE}, \mathrm{NE}$, and $\mathrm{fNOB}$ ), was calculated to rank parameters 316 (Figure S2). The most sensitive parameter is $\mu_{\max }^{\mathrm{AOB}}$, followed by 317 $K_{\mathrm{I}, \mathrm{FA}}^{\mathrm{AOB}}, \mu_{\max }^{\mathrm{NOB}}, K_{\mathrm{I}, \mathrm{FA}}^{\mathrm{NOB}}, K_{\mathrm{O}_{2}}^{\mathrm{AOB}}$, and $K_{\mathrm{O}_{2}}^{\mathrm{NOB}}$. The ranking shows that ${ }_{318}$ $\mu_{\max }$ is the most determinant among all kinetic parameters in 319 nitrogen conversion simulations. It is consistent with the 320 sensitivity analysis of Wang et al. ${ }^{35}$ who ranked kinetic 321 parameters in terms of nitritation performance and biofilm 322 development in nitrifying biofilm reactors. The higher 323 sensitivity regarding performance within the biofilm (Figure 324 S2B) versus the bulk (Figure S2A) suggests that in situ 325 microprofiling data is more informative in model calibration 326 than bulk measurements, which were typically used. ${ }^{22,38} 327$ Therefore, microprofiling measurements $\left(\mathrm{NH}_{4}{ }^{+}, \mathrm{NO}_{2}{ }^{-}, 328\right.$ $\mathrm{NO}_{3}{ }^{-}$, and $\left.\mathrm{DO}\right)$ in the first aeration hour at steady state 329 were used to calibrate sensitive parameter(s). Microprofiles in 330 the last aeration hour $\left(\mathrm{NH}_{4}{ }^{+}, \mathrm{NO}_{2}{ }^{-}, \mathrm{NO}_{3}{ }^{-}\right.$, and $\left.\mathrm{DO}\right)$ and bulk 331 profiles during an intermittent aeration cycle $\left(\mathrm{NH}_{4}^{+}, \mathrm{NO}_{2}^{-}, 332\right.$ $\mathrm{NO}_{3}{ }^{-}, \mathrm{DO}$, and $\mathrm{pH}$ ) representing the reactor performance at 333 steady state were used for validation. Additional validation of 334 the model and its parameter estimates was obtained by fitting 335 the initial reactor performance $\left(\mathrm{NH}_{4}{ }^{+}, \mathrm{NO}_{2}{ }^{-}\right.$, and $\left.\mathrm{NO}_{3}{ }^{-}\right)$when 336 operated in batch start-up mode and by fitting the biofilm 337 performance $\left(\mathrm{NH}_{4}{ }^{+}, \mathrm{NO}_{2}^{-}, \mathrm{NO}_{3}{ }^{-}\right.$, and $\left.\mathrm{pH}\right)$ of a separately 338 operated MABR under different $\mathrm{NH}_{4}^{+}$surface loadings. 339

By fitting the most sensitive parameter, $\mu_{\max }^{\mathrm{AOB}}$, in the reported 340 range, ${ }^{12}$ the RMSE decreased to 0.5 and the deviation in $\mathrm{NO}_{3}{ }^{-} 341$ fitting contributed the most to the error. Thus, the next most 342 sensitive parameter, $\mu_{\max }^{\mathrm{NOB}}$, in $\mathrm{NO}_{3}{ }^{-}$sensitivity ranking (Figure 343 S3) was added to the calibration and RMSE decreased to 0.1. 344 Values of $\mu_{\max }^{\mathrm{AOB}}$ and $\mu_{\max }^{\mathrm{NOB}}$ were within a reasonable range: the 345 estimated maximum growth rates at the optimal $\mathrm{pH}$ were 2.35346 $\mathrm{d}^{-1}$ for $\mathrm{AOB}$ and $2.15 \mathrm{~d}^{-1}$ for NOB (Table 1). In the data $347 \mathrm{tl}$

Table 1. Kinetic Parameter Values of AOB and NOB in the

\begin{tabular}{|c|c|c|c|}
\hline kinetic parameters & AOB & NOB & references \\
\hline $\begin{array}{l}\mu_{\max }: \text { the maximum specific growth } \\
\text { rate, } 1 / \mathrm{d}\end{array}$ & $\begin{array}{l}2.35 \\
\left(2.72^{a}\right)\end{array}$ & $\begin{array}{l}2.15 \\
\left(1.75^{a}\right)\end{array}$ & this study \\
\hline $\begin{array}{l}K_{\mathrm{O}_{2}}: \text { half-saturation coefficient for } \\
\mathrm{O}_{2}, \mathrm{mg} / \mathrm{L}\end{array}$ & 0.6 & 1.2 & $\begin{array}{l}\text { Hiatt and } \\
\text { Grady }^{28}\end{array}$ \\
\hline$Y:$ autotrophic yield, $\mathrm{mgCOD} / \mathrm{mgN}$ & 0.18 & 0.06 & $\begin{array}{l}\text { Hiatt and } \\
\text { Grady }^{28}\end{array}$ \\
\hline $\begin{array}{l}K_{\mathrm{FA}}^{\mathrm{AOB}}, K_{\mathrm{FNA}}^{\mathrm{NOB}}: \text { half-saturation } \\
\text { coefficient, mg/L }\end{array}$ & 0.0075 & 0.0001 & $\begin{array}{l}\text { Hiatt and } \\
\text { Grady }^{28}\end{array}$ \\
\hline $\begin{array}{l}K_{\mathrm{I}, \mathrm{FA}}: \text { free ammonia inhibition } \\
\text { coefficient, } \mathrm{mg} / \mathrm{L}\end{array}$ & 1 & 0.2 & $\begin{array}{l}\text { Hiatt and } \\
\text { Grady }^{28}\end{array}$ \\
\hline $\begin{array}{l}K_{\mathrm{I}, \mathrm{FNA}}: \text { free nitrous acid inhibition } \\
\text { coefficient, } \mathrm{mg} / \mathrm{L}\end{array}$ & 0.1 & 0.04 & $\begin{array}{l}\text { Hiatt and } \\
\text { Grady }^{28}\end{array}$ \\
\hline$b_{\max }:$ decay coefficient, $1 / \mathrm{d}$ & 0.17 & 0.073 & Hao et al. $^{34}$ \\
\hline $\mathrm{pH}_{\mathrm{opt}}(\omega):$ optimal $\mathrm{pH}$ & $8.4(3.2)$ & $7.7(2.4)$ & Park et al. ${ }^{13}$ \\
\hline
\end{tabular}
Calibrated Model

${ }^{a}$ Default growth rates in ASMN with temperature correction $\left(33^{\circ} \mathrm{C}\right)$.

fitting, the error function was bounded, but $\mu_{\max }^{\mathrm{AOB}}$ and $\mu_{\max }^{\mathrm{NOB}} 348$ were highly correlated indicating a poorly identifiable parameter 349 set. Model evaluations were, however, not affected by changes 350 in the $\mu_{\max }^{\mathrm{AOB}}(2.35-2.85)$ and $\mu_{\max }^{\mathrm{NOB}}(2.15-2.55)$ best-fit 351 parameter value region (Figure S3D, approximate $>99 \% 352$ confidence region: $\left.\mu_{\max }^{\mathrm{AOB}}, 2.25-2.95 ; \mu_{\max }^{\mathrm{NOB}}, 2.06-2.66\right) .353$ Predicted microprofiles agree with measurements in the first 354 aeration hour at steady state (Figure $1 \mathrm{~A}$ ): $\mathrm{NH}_{4}{ }^{+}$is consumed $355 \mathrm{fl}$ along biofilm depth and $\mathrm{NO}_{2}{ }^{-}$is produced; $\mathrm{NO}_{3}{ }^{-}$remains at 356 lower concentrations than $\mathrm{NO}_{2}{ }^{-}$within the biofilm; DO 357 penetrates $60 \mu \mathrm{m}$ into the biofilm base. The greatest divergence 358 

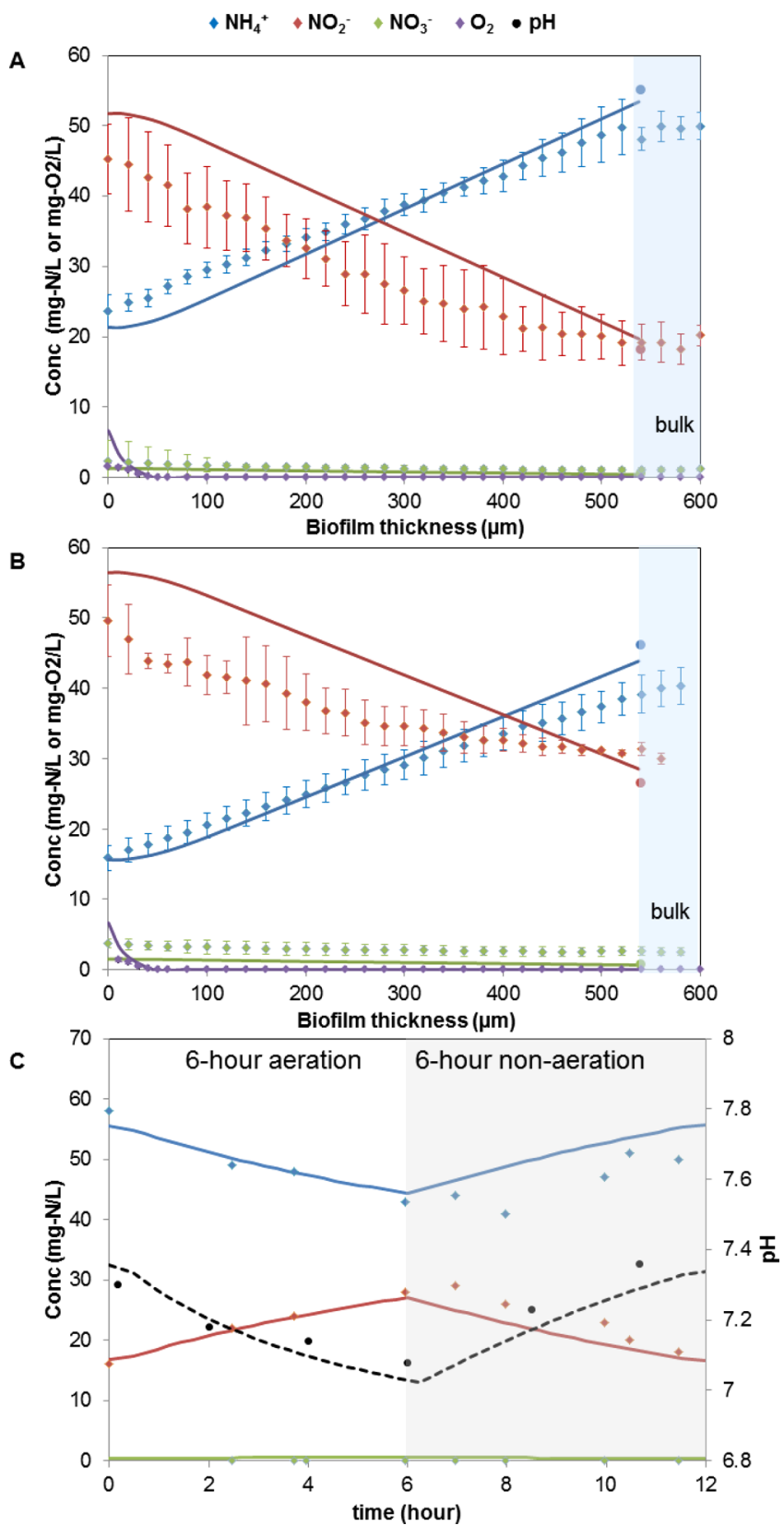

Figure 1. Experimental (discrete symbols) and predicted (line) concentrations in MABR at steady state (A) microprofiles in the first aeration hour, (B) microprofiles in the last aeration hour, and (C) bulk profiles during a $12 \mathrm{~h}$ intermittent aeration cycle. For each microprofile, replicates $(n>3)$ were made and the average was shown.

359 in the overall fitting corresponds to $\mathrm{NO}_{2}{ }^{-}$at the biofilm base $(6$ $360 \mathrm{mg}-\mathrm{N} / \mathrm{L}$ ) but only overestimates FNA concentrations by 0.002 $361 \mathrm{mg}-\mathrm{N} / \mathrm{L}$. Errors in DO fitting at the membrane-biofilm 362 interface $(6.6 \mathrm{mg} / \mathrm{L}$ predicted versus $1.7 \mathrm{mg} / \mathrm{L}$ measured) have 363 a minor influence on the oxygen competition between $\mathrm{AOB}$ 364 and NOB (Table S4), consistent with Lackner and Smets ${ }^{39}$ 365 who reported that oxygen concentrations at interfaces were not 366 decisive in nitritation performance in MABRs. Additionally, 367 uncertainty in measuring the interface DO could be caused by 368 microbial activities on the membrane and an efficiency factor $E$ $369(1.3-4.3)$ was suggested to correct measured values. ${ }^{36}$

370 MSNBM predicts consistent profiles in the different model 371 validations. It predicted lower $\mathrm{NH}_{4}{ }^{+}$and higher $\mathrm{NO}_{2}{ }^{-}$within the biofilm in the last aeration hour (Figure 1B) and uniform 372 dynamic variations of bulk concentrations during a $12 \mathrm{~h} 373$ intermittent aeration cycle. For example, it captured the $\mathrm{pH} 374$ decreases in the $6 \mathrm{~h}$ aeration phase and increases in the $6 \mathrm{~h} 375$ nonaeration phase (Figure 1C). It also predicted simultaneous 376 production of $\mathrm{NO}_{2}^{-}$and $\mathrm{NO}_{3}^{-}$in the batch mode data 377 validation (Figure S4A) and predicted $\mathrm{NH}_{4}{ }^{+}$consumption and 378 $\mathrm{NO}_{2}{ }^{-}$production following the tendencies observed in MABR2 379 (Figure S4B). Janus coefficients were around $1.9( \pm 0.5), 380$ showing that the RMSEs were within the same order of 381 magnitude in calibration and validations.

3.2. Model-Based Exploration of NOB Suppression in 383 Intermittently Aerated MABRs. NOB suppression is the 384 result of indirect and direct (competitive) interactions between 385 $\mathrm{AOB}$ and $\mathrm{NOB}$ in the local environment. Net microbial 386 activities are captured in the specific growth rates: biomass 387 types with the higher specific growth rate will win the local 388 competition. In the studied system, oxygen was provided 389 intermittently from membrane lumen. The biomass type with 390 the higher specific growth rate (AOB or NOB) thus dominated 391 the oxygen utilization.

Consistent with experimental reactor operations, simulations 393 were initiated with fully nitrifying biomass and subject to 394 intermittent aeration. Both simulation and experimental data 395 showed that after 2 weeks in intermittent aeration bulk $\mathrm{N} 396$ concentrations became stable, especially $\mathrm{NO}_{3}{ }^{-}$was below 1397 $\mathrm{mg}-\mathrm{N} / \mathrm{L}$ indicating efficient suppression of NOB activity 398 (Figure S9). To illustrate the competition in the first nitrifying 399 stage, profiles of specific growth rates of AOB and NOB during 400 an aeration cycle $(6 \mathrm{~h})$ are plotted at day 15 (Figure 2A). The $401 \mathrm{f} 2$ averaged $\mu$ at time intervals shows kinetic variations over time: 402 (1) $0-15 \mathrm{~min}$, with the onset of aeration microbial activities 403 recover from the previous nonaeration period and increase 404 dramatically; (2) 15-180 min, AOB activity becomes stable, 405 while NOB activity still recovers; (3) 180-360 min, both AOB 406 and NOB activity reach pseudosteady state. The model shows 407 the ratio of $\mu_{\mathrm{AOB}}$ to $\mu_{\mathrm{NOB}}$ increases in the intermittent aeration, 408 compared to the ratio of $\mu_{\max }^{\mathrm{AOB}}$ to $\mu_{\max }^{\mathrm{NOB}}$ in continuous aeration 409 $(1.5 \pm 0.15$ versus 1.1$)$. AOB preferentially utilize oxygen to 410 support growth while NOB are outcompeted or their activity is 411 suppressed.

To assess the relative contribution of $\mathrm{DO} / \mathrm{pH}$ effects on 413 NOB suppression, individual factors influencing growth rates 414 were calculated spatially (at different biofilm depths) and 415 temporally (at different times during the cycle). Considering 416 the effective DO penetration depth, only results in the first 100417 $\mu \mathrm{m}$ at the biofilm base are shown (Figure $2 \mathrm{~B}$ ).

3.2.1. DO Limitation in $N O B$ Suppression. $\mathrm{O}_{2}$ is a growth 419 substrate for both $\mathrm{AOB}$ and $\mathrm{NOB}$. In counter-diffusion 420 biofilms, $\mathrm{O}_{2}$ is provided via the lumen and $\mathrm{NH}_{4}{ }^{+}$via the 421 bulk. In the biofilm, DO penetrates only $60 \mu \mathrm{m}$ during aeration 422 periods with the highest concentration at the membrane- 423 biofilm interface (biofilm depth $=0 \mu \mathrm{m}$ ), presenting spatial 424 variations (Figure S5A). Besides, DO varies over time during 425 aeration cycles. DO at the membrane-biofilm interface is 0426 $\mathrm{mg} / \mathrm{L}$ at the onset of aeration and quickly increases to the 427 maximum concentration within $15 \mathrm{~min}$. Afterward, DO 428 concentrations within the biofilm remain stable until the end 429 of aeration.

430

The DO limitation effect was evaluated on the basis of 431 oxygen concentrations within the biofilm (Figure 2B, 1, DO 432 limitation). In aeration periods, during the first $15 \mathrm{~min}, \mathrm{DO} 433$ strongly limits both $\mathrm{AOB}$ and NOB activities. During the 434 
A
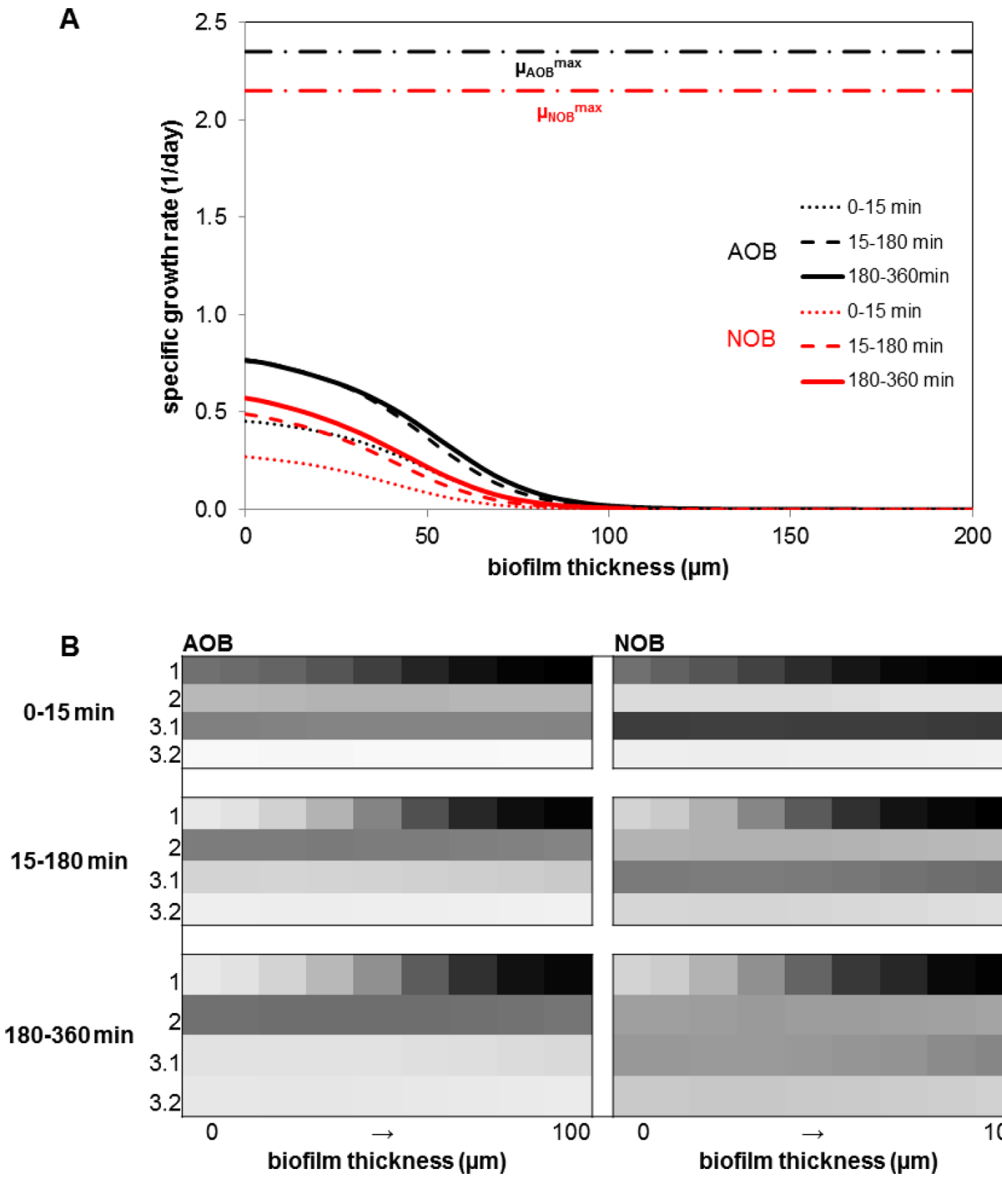

NOB

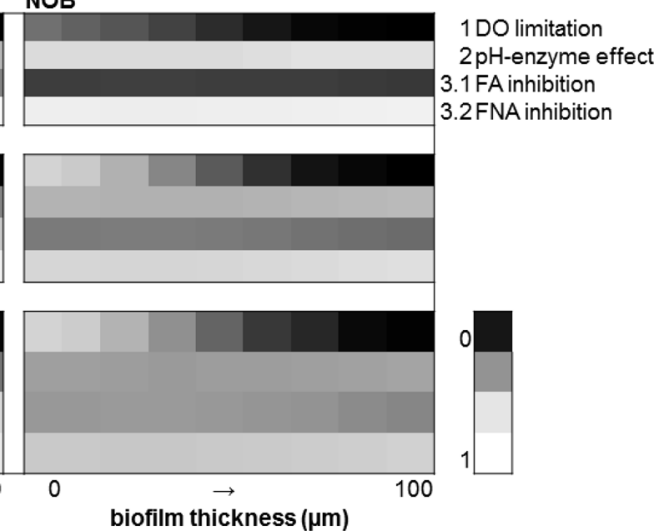

Figure 2. (A) Specific growth rates of $A O B$ and NOB within the biofilm in a $6 \mathrm{~h}$ aeration period at day 15 (AOB, black; NOB, red). (B) Individual effect on $\mathrm{AOB}$ and $\mathrm{NOB}$ within the $100 \mu \mathrm{m}$-aerated biofilm base in a $6 \mathrm{~h}$ aeration period at day 15 (0, strong limitation/inhibition effect; 1 , no limitation/inhibition effect).

435 following period, the limitation is alleviated as DO increases 436 and stabilizes but still remains strong above $30 \mu \mathrm{m}$. With a 437 lower DO affinity. NOB are more oxygen-limited than AOB. 438 However, the relatively stronger limitation to NOB is 439 insignificant in its suppression. Model results show that oxygen 440 transfer and its diffusion mostly affects $\mathrm{NH}_{4}^{+}$oxidation 441 efficiency rather than nitritation efficiency (Table S7).

442 3.2.2. $\mathrm{pH}$-Enzyme Effect on NOB Suppression. Because $\mathrm{pH}$ 443 affects $\mathrm{AOB} / \mathrm{NOB}$ kinetics directly and indirectly, it is 444 necessary to incorporate $\mathrm{pH}$ effects in models. ${ }^{14,40}$ Here, 445 MSNBM predicts local $\mathrm{pH}$ values within the biofilm and the 446 response to transient aeration phases (Figure S5B). While 447 measurements showed that bulk $\mathrm{pH}$ remained relatively stable $448( \pm 0.2), \mathrm{pH}$ within the biofilm, especially in the DO-penetrated 449 zone, showed considerable variations $( \pm 0.6)$. At the onset of 450 aeration, the model indicates a transient $\mathrm{pH}$ upshift at the 451 biofilm base $(0-15 \mathrm{~min})$. The accumulated alkalinity is 452 attributed to continuous $\mathrm{CO}_{2}$ diffusion from the biofilm base 453 to the membrane lumen where $\mathrm{N}_{2}$ gas flows through in the 454 previous nonaeration period and slight denitrification activities. 455 As aeration continues, $\mathrm{pH}$ decreases due to proton production 456 associated with $\mathrm{NH}_{4}{ }^{+}$oxidation. Simulations predict that $\mathrm{pH}$ 457 within the biofilm becomes lower than in the bulk after $1 \mathrm{~h}$ of 458 aeration and decreases slowly afterward. At the end of aeration, $459 \mathrm{pH}$ at the biofilm base is 0.4 units lower than the average bulk $460 \mathrm{pH}$, which will increase again in the following nonaerated 461 phase. Thus, $\mathrm{pH}$ varies periodically in the intermittently aerated 462 biofilms, a pattern similar but slower than DO variations.
The $\mathrm{pH}$-enzyme effect was assessed on the basis of local $\mathrm{pH} 463$ values (Figure 2B, 2, pH-enzyme effect). It favors NOB 464 growth over $\mathrm{AOB}$ as $\mathrm{NOB}$ have a lower $\mathrm{pH}_{\text {opt }}$ (NOB: 7.7465 versus $\mathrm{AOB}$ : 8.4) and $\mathrm{pH}$ varies in the optimal range for its 466 growth. Moreover, the $\mathrm{pH}$-enzyme effect is also insignificant in 467 the overall $\mathrm{AOB} / \mathrm{NOB}$ competition due to their robust growth 468 in broad $\mathrm{pH}$ ranges and the relatively small $\mathrm{pH}$ variations in the 469 system.

470

3.2.3. $\mathrm{pH}$ Substrate-Speciation Effects on NOB Suppres- 471 sion. FA/FNA concentrations rely on $\mathrm{pH}$ values as well as total 472 $\mathrm{NH}_{4}{ }^{+} / \mathrm{NO}_{2}{ }^{-}$concentrations. In counter-diffusion biofilms, 473 $\mathrm{NH}_{4}^{+}$, provided via the bulk, is oxidized at the biofilm base 474 producing $\mathrm{NO}_{2}{ }^{-}$which diffuses backward into the bulk. ${ }^{10}$ On 475 the basis of ionic $\mathrm{N}$ concentrations, FA and FNA speciation 476 synchronizes with $\mathrm{pH}$ variations (Figure S5C,D). For instance, 477 at the onset of aeration, FA concentration is high due to $\mathrm{NH}_{4}^{+} 478$ and alkalinity accumulation from the previous nonaeration 479 period. During the following aeration period, FA concentration 480 decreases, as $\mathrm{pH}$ drops and $\mathrm{NH}_{4}{ }^{+}$consumption continues. On 481 the other hand, FNA shows reversed variations: increasing as 482 aeration progresses and with biofilm depth as a result of the 483 proton and $\mathrm{NO}_{2}^{-}$production.

The $\mathrm{pH}$ substrate-speciation effect was assessed on the basis 485 of FA/FNA concentrations within the biofilm (Figure 2B, 3, 486 FA/FNA inhibition). During the first $15 \mathrm{~min}$, FA strongly 487 inhibits $\mathrm{AOB} / \mathrm{NOB}$ microbial activities $\left(\mathrm{FA}>K_{\mathrm{I}, \mathrm{FA}}\right)$. Afterward, 488 the inhibition is alleviated as FA decreases. Noticeably, FA 489 inhibits $\mathrm{AOB}$ and $\mathrm{NOB}$ in different ways: the inhibition effect 490 
Table 2. Predicted Nitritation Efficiencies (NE, \%) in Various Intermittent Aeration Strategies

\begin{tabular}{|c|c|c|c|c|c|c|}
\hline \multirow[b]{2}{*}{ simulation case } & \multicolumn{2}{|c|}{ influent $^{b}$} & \multicolumn{4}{|c|}{ effluent (bulk) } \\
\hline & $\mathrm{NH}_{4}^{+}(\mathrm{mg}-\mathrm{N} / \mathrm{L})$ & buffer capacity $^{b}$ & $\mathrm{NH}_{4}^{+}(\mathrm{mg}-\mathrm{N} / \mathrm{L})$ & $\mathrm{pH}$ & $\mathrm{FA}^{c}(\mathrm{mg}-\mathrm{N} / \mathrm{L})$ & $\mathrm{NE}_{\text {normalized }}{ }^{d}$ \\
\hline continuous & 75 & 2.1 & 39 & 6.96 & 0.27 & 0.01 \\
\hline A: $6+6^{a}$ & 75 & 2.1 & $53.0 \pm 5$ & $7.23 \pm 0.15$ & 0.71 & $1.00^{d}$ \\
\hline B: $1+1$ & 75 & 2.1 & $52.5 \pm 1$ & $7.22 \pm 0.02$ & 0.69 & 0.73 \\
\hline C: $12+12$ & 75 & 2.1 & $53.1 \pm 10$ & $7.25 \pm 0.25$ & 0.78 & 0.79 \\
\hline $\mathrm{D}: 8+4$ & 75 & 2.1 & $47.8 \pm 4$ & $7.14 \pm 0.15$ & 0.52 & 0.41 \\
\hline E: $6+6$ & 100 & 2.1 & $72.0 \pm 7$ & $7.25 \pm 0.15$ & 1.02 & 1.74 \\
\hline F: $6+6$ & 50 & 2.1 & $35.0 \pm 3$ & $7.20 \pm 0.15$ & 0.45 & 0.21 \\
\hline G: $6+6$ & 50 & 5 & $31.2 \pm 5$ & $7.41 \pm 0.10$ & 0.64 & 0.83 \\
\hline
\end{tabular}

${ }^{a}$ Aeration strategy $6+6$ meant a $12 \mathrm{~h}$ intermittent aeration cycle consisting of a $6 \mathrm{~h}$ aeration phase and a 6 h nonaeration phase. ${ }^{b}$ Buffer capacity in the influent was recorded as the molar ratio of bicarbonate $\left(\mathrm{HCO}_{3}{ }^{-}\right)$to ammonium $\left(\mathrm{NH}_{4}^{+} \mathrm{N}\right) .{ }^{c} \mathrm{FA}$ was calculated with the averaged $\mathrm{NH}_{4}^{+}$ concentrations and bulk pH during a full aeration cycle (eq 6). ${ }^{d}$ For a clear comparison, NE was normalized to the nitritation efficiency in the default simulation case A $(\mathrm{NE}=48.5 \%)$. MSNBM was run in continuous aeration (200 days) to achieve a mature nitrifying biofilm, followed by various intermittent aeration strategies: $(A-D)$ different intermittent aeration but the same influent; $(A, E-G)$ the same aeration intermittency but different influent concentrations. NEs in the NOB suppression process in intermittent aeration were recorded (e.g., at day 215) (Table S6). In simulations E$\mathrm{G}$, oxygen loadings proportionally varied with $\mathrm{NH}_{4}{ }^{+}$influent concentrations (more simulations in Table S8).

491 remains strong for $\mathrm{NOB}$ throughout the aeration period (from 4920.26 to 0.62 ), while it obviously weakens for AOB (from 0.54 493 to 0.89 ). FA inhibition rapidly becomes the most determinant 494 factor in suppressing NOB over AOB. As FNA concentrations 495 are always an order of magnitude lower than $K_{\mathrm{I}, \mathrm{FNA}}$ its 496 inhibition effect on microbial activities is always minor thereby 497 contributing little to NOB suppression.

498 Besides the inhibitor effect $\left(K_{\mathrm{I}} /\left(K_{\mathrm{I}}+S\right)\right)$, FA/FNA exhibit 499 the substrate limitation effect $\left(S /\left(K_{S}+S\right)\right)$ in biological 500 processes (eq 2). However, FA and FNA concentrations are far 501 above the substrate affinities ( $K_{\mathrm{FA}}^{\mathrm{AOB}}$ and $K_{\mathrm{FNA}}^{\mathrm{NOB}}$ ) in the system, 502 making the substrate limitation effects negligible.

503 3.2.4. Implication of Model-Based NOB Suppression. 504 Overall, FA inhibition caused by $\mathrm{pH}$ substrate speciation is 505 the crucial factor in suppressing NOB in the intermittently 506 aerated biofilm reactors. Nitritation success is insensitive to 507 oxygen affinity constants or DO concentrations at the 508 membrane-biofilm interface, a conclusion different from 509 previous studies. ${ }^{41,42}$ Downing and Nerenberg ${ }^{22}$ suggested 510 manipulating interface DO as an effective method to control 511 shortcut nitrification in MABRs: with a lower interface DO, 512 more $\mathrm{NO}_{2}{ }^{-}$accumulated. However, their biofilms performed at 513 low nitrification rates with a low influent $\mathrm{NH}_{4}{ }^{+}$concentration, 3 $514 \mathrm{mg}-\mathrm{N} / \mathrm{L}$, suggesting little $\mathrm{FA}$ inhibition and no $\mathrm{NO}_{2}{ }^{-}$ 515 accumulation or significant $\mathrm{pH}$ gradients. The single $\mathrm{DO}$ 516 gradient within the biofilm presents the interface $\mathrm{DO}$ as having 517 a key role in nitritation success. This method might not apply 518 for N-rich wastewater treatment. For example, Lackner and 519 Smets $^{39}$ concluded that nitritation success based only on 520 interface DO was not possible in a counter-diffusion biofilm 521 with high influent $\mathrm{NH}_{4}^{+}$concentrations $(20-800 \mathrm{mg}-\mathrm{N} / \mathrm{L})$, 522 and nitritation efficiency was not predicted from oxygen affinity 523 constants.

524 Counter- and codiffusion biofilms have different mechanisms 525 of NOB suppression due to different spatial structures and 526 population distributions. ${ }^{35,38,39}$ In counter-diffusion biofilms, 527 the theoretically optimal habitat for NOB is the biofilm base, 528 where both $S_{\mathrm{O}_{2}} / K_{\mathrm{O}_{2}}$ and $S_{\mathrm{FNA}} / K_{\mathrm{FNA}}$ have the highest values. In ${ }_{529}$ contrast, the base is not the optimal for AOB growth, as $S_{\mathrm{O}_{2}} /$ $530 K_{\mathrm{O} 2}$ and $S_{\mathrm{FA}} / K_{\mathrm{FA}}$ cannot have the maximum at the same spatial 531 position. Outcompeting NOB can be more difficult in counter532 diffusion over codiffusion biofilms, where microbes (AOB and $533 \mathrm{NOB}$ ) share the optimal habitats at the biofilm top near the biofilm/liquid interphase. Others have similarly observed that 534 NOB could survive better in counter- versus codiffusion 535 biofilms, even when operated under constant oxygen limited 536 $(\mathrm{DO}<0.1 \mathrm{mg} / \mathrm{L})$ and high $\mathrm{pH}(8.0-8.3)$ conditions in the 537 bulk. $^{35}$ The inherent system geometry of membrane-aerated 538 biofilms complicates NOB inhibition/washout. Besides, when 539 applying intermittent aeration, periodic $\mathrm{pH}$ variations at the 540 biofilm base exert a significant effect on NOB dynamics in 541 counter-diffusion biofilms because of continuous $\mathrm{CO}_{2}$ diffusion 542 to the gas lumen. However, such $\mathrm{pH}$ variations are not expected 543 in codiffusion biofilms. Many studies have highlighted the 544 benefits of low DO with high FA to maintain shortcut $\mathrm{NH}_{4}^{+}{ }_{545}$ removal in codiffusion biofilms. ${ }^{17,43}$ Park et al. ${ }^{3}$ explored 546 simultaneous effects of DO and FA/FNA in lab-scale 547 codiffusion nitrifying biofilms and found that $\mathrm{NO}_{2}{ }^{-}$accumu- 548 lated due to DO limitation or FA inhibition and long-term 549 NOB suppression could not be maintained without DO 550 limitation involved. The results were consistent with 551 Brockmann and Morgenroth ${ }^{44}$ who suggested that oxygen 552 limitation was the main mechanism for NOB suppression and 553 FA inhibition was not necessarily required in codiffusion 554 biofilms. However, DO limitation in nitritation counter- 555 diffusion biofilms appears not as significant as reported for 556 codiffusion biofilms, consistent with the observation that 557 nitritation could not be achieved by solely manipulating air 558 pressure in the membrane lumen in MABRs. ${ }^{21}$

559

3.3. Potential Explanation of NOB Suppression in the 560 Study of Pellicer-Nàcher et al. ${ }^{21}$ To answer why $\mathrm{NO}_{2}{ }^{-} 561$ accumulated after switching from continuous to intermittent 562 aeration in MABRs, simulations were carried out with the 563 calibrated MSNBM in continuous aeration for 200 days 564 followed by intermittent aeration $(6 \mathrm{~h}$ aeration and $6 \mathrm{~h} 565$ nonaeration cycles). The simulation shows a nitrifying biofilm 566 during continuous aeration $(\mathrm{NE}=0 \%$ ) indicating no NOB 567 suppression (Table 2, continuous aeration). After switching to $568 \mathrm{t} 2$ intermittent aeration, the model predicts NOB suppression: 569 $\mathrm{NO}_{3}{ }^{-}$decrease and NE increase (Table 2- strategy A, Figure 570 S6). To find the critical factor for NOB suppression, variations 571 of the individual $\mathrm{pH} / \mathrm{DO}$ effect on $\mathrm{AOB} / \mathrm{NOB}$ competition 572 were assessed: each effect $\frac{\text { effect }_{\mathrm{AOB}}}{\text { effect }_{\mathrm{NOB}}}$ in intermittent aeration (for ${ }_{573}$ instance at day 215) was normalized by its value during 574 continuous aeration. A value higher than 1 means the effect 575 
576 favors NOB suppression in intermittent aeration, and a value 577 lower than 1 indicates it favors NOB growth.

578 Only FA inhibition is identified to favor $\mathrm{NO}_{2}{ }^{-}$accumulation 579 after switching the aeration strategy, while DO limitation, $\mathrm{pH}-$ 580 enzyme effect, and FNA inhibition remain unchanged (Figure 581 S7). FA inhibition shows certain varying patterns in 582 intermittent aeration: (1) overall, it is enhanced due to an 583 increased residual $\mathrm{NH}_{4}{ }^{+}$; (2) it is particularly strong during the 584 first $15 \mathrm{~min}$ of aeration. The simulated increase of residual $585 \mathrm{NH}_{4}^{+}$after changing to intermittent aeration was also observed 586 in the study of Pellicer-Nàcher et al.: ${ }^{21}$ in reactor $\mathrm{B}$, bulk $\mathrm{NH}_{4}{ }^{+}$ 587 increased by $100 \mathrm{mg} / \mathrm{L}$ at stages 1 and 2 (intermittent aeration) 588 compared to stage 0 (continuous aeration). Compared to 589 continuous aeration, MABRs in intermittent aeration display a 590 trade-off between $\mathrm{NH}_{4}{ }^{+}$removal efficiency and nitritation 591 efficiency (Table 2). Nitritation is assisted by the evaluated 592 residual $\mathrm{NH}_{4}{ }^{+}$, which underlines the importance of a minimum $593 \mathrm{NH}_{4}{ }^{+}$concentration in the bulk. Pérez et al. ${ }^{18}$ also highlighted 594 the need for minimum residual $\mathrm{NH}_{4}^{+}$for $\mathrm{NOB}$ suppression in 595 codiffusion biofilms but attributed the nitritation success to 596 differential oxygen limitation rather than FA inhibition, as NOB 597 were outcompeted due to the strong oxygen limiting conditions 598 imposed by a high residual $\mathrm{NH}_{4}^{+}$. The strong $\mathrm{FA}$ inhibition at 599 the onset of aeration is due to $\mathrm{pH}$ upshifts at the biofilm base in 600 the previous anoxic phases. It causes a longer lag phase of NOB 601 activity over AOB, which could be another reason for the 602 nitritation success. Theoretically, NOB locate at the biofilm 603 base, if enriched in MABRs; thus, $\mathrm{pH}$ upshift at the base is 604 more efficient to prompt FA inhibition than increasing bulk $\mathrm{pH}$. 605 This lag phase has also been observed in other intermittently 606 aerated systems. ${ }^{45,46}$ Kornaros et al. ${ }^{47}$ and Gilbert et al. ${ }^{48}$ 607 attributed the lag phase to a long (enzyme) reactivation time in 608 NOB nitrogen metabolism after anoxic exposure in batch 609 continuous stirred-tank reactors. However, the possibility for $610 \mathrm{pH}$ variations was not considered in those studies, even though $611 \mathrm{CO}_{2}$ stripping could slowly increase bulk $\mathrm{pH}^{49}$

612 3.4. Nitritation in Various Intermittent Aeration 613 Strategies. For an intermittent aeration system with certain $614 \mathrm{NH}_{4}^{+} / \mathrm{O}_{2}$ surface loadings, the aeration duration determines 615 residual $\mathrm{NH}_{4}^{+}$concentrations: a longer aeration lowers residual $616 \mathrm{NH}_{4}{ }^{+}$. The aeration intermittency determines $\mathrm{pH}$ upshift times 617 and the variation range of bulk concentrations: a higher 618 frequency causes more $\mathrm{pH}$ upshifts and a narrow variation 619 range. This information can be utilized to optimize intermittent 620 aeration strategies for efficient nitritation in MABRs (Table 2). 621 MSNBM simulation shows that a higher aeration intermittency 622 can accelerate NOB suppression ( $\mathrm{A}$ and $\mathrm{C}$ ) due to more times 623 of $\mathrm{pH}$ upshift in nonaeration phases to retard NOB activity 624 while slightly affecting $\mathrm{AOB}$ activity or decelerate NOB 625 suppression ( $\mathrm{B}$ and $\mathrm{A}$ ) due to the relatively high bulk $\mathrm{NH}_{4}^{+}$ $626(\mathrm{pH})$ at the onset of aeration phases even though the averaged 627 bulk concentrations are the same. Longer aeration duration (D) 628 leads to a slower nitritation process but a higher $\mathrm{NH}_{4}{ }^{+}$removal 629 efficiency, while keeping the same aeration intermittency. It is 630 consistent with the observation in Mota et al. ${ }^{50}$ that 631 intermittently aerated reactors with longer anoxic phase had 632 the lower NOB abundance and relatively higher $\mathrm{NH}_{4}^{+}$effluent 633 concentrations. Both studies suggest that the maximum 634 aeration duration should be set to ensure nitritation success 635 in intermittent aeration, and a specific to the treated wastewater 636 ratio of aeration to nonaeration phase is needed to balance $637 \mathrm{NOB}$ suppression against $\mathrm{NH}_{4}^{+}$removal. ${ }^{51}$ Simulation with 638 high $\mathrm{NH}_{4}^{+}$concentrations predicts fast nitritation in the intermittent aeration (E) and vice versa slow nitritation with 639 low influent $\mathrm{NH}_{4}^{+}(\mathrm{F})$. Further simulation with low $\mathrm{NH}_{4}^{+}{ }_{640}$ concentrations but high bulk pH $(\mathrm{G})$ shows efficient nitritation, 641 confirming a key factor in NOB suppression was bulk FA rather 642 than residual $\mathrm{NH}_{4}^{+}$(more simulations in Table S8). In an 643 intermittent aeration regime, the bulk FA can provide a rapid 644 indicator of the nitritation potential of MABRs (Figure S10). 645 MSNBM simulations reveal that aeration duration and 646 intermittency control the performance of intermittently aerated 647 nitrifying biofilms: longer aeration duration ensures a higher 648 $\mathrm{NH}_{4}{ }^{+}$removal efficiency yet impedes NOB suppression; higher 649 aeration intermittency presents unchanged $\mathrm{NH}_{4}^{+}$removal 650 performance, while its effect on NOB suppression should be 651 evaluated under specific conditions. Following this model-based 652 analysis, experimental validation of model predictions is 653 warranted.

In conclusion, we provide experimental evidence that 655 intermittent aeration supports efficient nitritation in membrane 656 aerated biofilm reactors (MABRs). A pH-explicit 1-D multi- 657 species nitrifying biofilm model (MSNBM) is developed and 658 calibrated: model analysis reveals that NOB suppression, 659 associated with intermittent aeration, is primarily governed by 660 periodic FA inhibition as the consequence of transient $\mathrm{pH} 661$ upshifts during nonaeration. These $\mathrm{pH}$ upshifts are mainly 662 caused by alkalinity increases due to $\mathrm{CO}_{2}$ stripping to the 663 membrane lumen (which also occurs during aeration) plus the 664 cessation of proton production (which only occurs during 665 aeration). In counter diffusion biofilms, $\mathrm{pH}$ effect is more 666 important than DO (limitation) effect on NOB suppression. 667 Both aeration intermittency and duration are effective control 668 factors to obtain nitritation success in intermittently mem- 669 brane-aerated biofilms, and maintaining nitritation and $\mathrm{NH}_{4}^{+} 670$ removal efficiency is more easily ensured if operated with high 671 buffer capacities.

\section{ASSOCIATED CONTENT}

\section{S Supporting Information}

The Supporting Information is available free of charge on the 675 ACS Publications website at DOI: 10.1021/acs.est.7b00463. 676

More detailed information on model description, model 677 simulations, and data analysis (PDF)

\section{AUTHOR INFORMATION}

*E-mail: bfsm@env.dtu.dk; tel: +45 4525 1600; fax: +45 4593681 2850 .

Barth F. Smets: 0000-0003-4119-6292

${ }^{\dagger}$ B.G.P.: Department of Chemical Engineering, University of 686 Bath, Claverton Down, BA2 7AY Bath, United Kingdom. $\quad 687$

Notes

The authors declare no competing financial interest.

\section{ACKNOWLEDGMENTS}

The authors would like to thank the China Scholarship Council 691 (CSC) for financial support to Y.M. and the Innovation Fund 692 Denmark (IFD) (Project LaGAS, File No. 0603-00523B) for 693 additional financial support. 


\section{$695 \square$ REFERENCES}

696 (1) Hellinga, C.; Schellen, A.; Mulder, J.; Vanloosdrecht, M.; 697 Heijnen, J. The sharon process: An innovative method for nitrogen 698 removal from ammonium-rich waste water. Water Sci. Technol. 1998, 69937 (9), 135-142.

700 (2) Jenicek, P.; Svehia, P.; Zabranska, J.; Dohanyos, M. Factors 701 affecting nitrogen removal by nitritation/denitritation. Water Sci. 702 Technol. 2004, 49 (5-6), 73-79.

703 (3) Park, S.; Chung, J.; Rittmann, B. E.; Bae, W. Nitrite accumulation 704 from simultaneous free-ammonia and free-nitrous-acid inhibition and 705 oxygen limitation in a continuous-flow biofilm reactor. Biotechnol. 706 Bioeng. 2015, 112 (1), 43-52.

707 (4) van Dongen, U.; Jetten, M. S.; van Loosdrecht, M. C. The 708 SHARON-Anammox process for treatment of ammonium rich 709 wastewater. Water Sci. Technol. 2001, 44 (1), 153-160.

710 (5) Kuenen, J. G. Anammox bacteria: from discovery to application. 711 Nat. Rev. Microbiol. 2008, 6 (4), 320-326.

712 (6) Sliekers, A. O.; Haaijer, S. C. M.; Stafsnes, M. H.; Kuenen, J. G.; 713 Jetten, M. S. M. Competition and coexistence of aerobic ammonium714 and nitrite-oxidizing bacteria at low oxygen concentrations. Appl. 715 Microbiol. Biotechnol. 2005, 68 (6), 808-817.

716 (7) Vadivelu, V. M.; Yuan, Z.; Fux, C.; Keller, J. The inhibitory effects 717 of free nitrous acid on the energy generation and growth processes of 718 an enriched Nitrobacter culture. Environ. Sci. Technol. 2006, 40 (14), $7194442-4448$.

720 (8) Terada, A.; Lackner, S.; Kristensen, K.; Smets, B. F. Inoculum 721 effects on community composition and nitritation performance of 722 autotrophic nitrifying biofilm reactors with counter-diffusion geome723 try. Environ. Microbiol. 2010, 12 (10), 2858-2872.

724 (9) Fux, C.; Huang, D.; Monti, A.; Siegrist, H. Difficulties in 725 maintaining long-term partial nitritation of ammonium-rich sludge 726 digester liquids in a moving-bed biofilm reactor (MBBR). Water Sci. 727 Technol. 2004, 49 (11-12), 53-60.

728 (10) Schramm, A.; De Beer, D.; Gieseke, A.; Amann, R. 729 Microenvironments and distribution of nitrifying bacteria in a 730 membrane-bound biofilm. Environ. Microbiol. 2000, 2 (6), 680-686. 731 (11) Shanahan, J. W.; Semmens, M. J. Alkalinity and pH effects on 732 nitrification in a membrane aerated bioreactor: An experimental and 733 model analysis. Water Res. 2015, 74, 10-22.

734 (12) Vannecke, T. P. W.; Volcke, E. I. P. Modelling microbial 735 competition in nitrifying biofilm reactors. Biotechnol. Bioeng. 2015, 112 736 (12), 2550-2561.

737 (13) Park, S.; Bae, W.; Chung, J.; Baek, S.-C. Empirical model of the $738 \mathrm{pH}$ dependence of the maximum specific nitrification rate. Process 739 Biochem. 2007, 42 (12), 1671-1676.

740 (14) Fumasoli, A.; Morgenroth, E.; Udert, K. M. Modeling the low $741 \mathrm{pH}$ limit of Nitrosomonas eutropha in high-strength nitrogen 742 wastewaters. Water Res. 2015, 83, 161-170.

743 (15) Carrera, J.; Jubany, I.; Carvallo, L.; Chamy, R.; Lafuente, J. 744 Kinetic models for nitrification inhibition by ammonium and nitrite in 745 a suspended and an immobilised biomass systems. Process Biochem. 746 2004, 39 (9), 1159-1165.

747 (16) Martin, K. J.; Picioreanu, C.; Nerenberg, R. Assessing microbial 748 competition in a hydrogen-based membrane biofilm reactor (MBfR) 749 using multidimensional modeling. Biotechnol. Bioeng. 2015, 112 (9), $750 \quad 1843-1853$.

751 (17) Park, S.; Bae, W.; Rittmann, B. E. Multi-Species Nitrifying 752 Biofilm Model (MSNBM) including free ammonia and free nitrous 753 acid inhibition and oxygen limitation. Biotechnol. Bioeng. 2010, 105 (6), 754 1115-1130.

755 (18) Pérez, J.; Lotti, T.; Kleerebezem, R.; Picioreanu, C.; van 756 Loosdrecht, M. C. M. Outcompeting nitrite-oxidizing bacteria in 757 single-stage nitrogen removal in sewage treatment plants: A model758 based study. Water Res. 2014, 66, 208-218.

759 (19) Casey, E.; Glennon, B.; Hamer, G. Review of membrane aerated 760 biofilm reactors. Resour. Conserv. Recycl. 1999, 27 (1-2), 203-215.

761 (20) Terada, A.; Yamamoto, T.; Igarashi, R.; Tsuneda, S.; Hirata, A. 762 Feasibility of a membrane-aerated biofilm reactor to achieve 763 controllable nitrification. Biochem. Eng. J. 2006, 28 (2), 123-130.
(21) Pellicer-Nàcher, C.; Sun, S.; Lackner, S.; Terada, A.; Schreiber, 764 F.; Zhou, Q.; Smets, B. F. Sequential aeration of membrane-aerated 765 biofilm reactors for high-rate autotrophic nitrogen removal: exper- 766 imental demonstration. Environ. Sci. Technol. 2010, 44 (19), 7628- 767 7634.

(22) Downing, L. S.; Nerenberg, R. Effect of oxygen gradients on the 769 activity and microbial community structure of a nitrifying, membrane- 770 aerated biofilm. Biotechnol. Bioeng. 2008, 101 (6), 1193-1204. 771

(23) Pellicer-Nàcher, C.; Sun, S.; Lackner, S.; Terada, A.; Schreiber, 772 F.; Zhou, Q.; Smets, B. F. Sequential aeration of membrane-aerated 773 biofilm reactors for high-rate autotrophic nitrogen removal: exper- 774 imental demonstration. Environ. Sci. Technol. 2010, 44 (19), 7628- 775 7634

(24) Zhu, S.; Chen, S. The impact of temperature on nitrification rate 777 in fixed film biofilters. Aquac. Eng. 2002, 26 (4), 221-237. 778 (25) Gieseke, A.; de Beer, D. Use of microelectrodes to measure in 779 situ microbial activities in biofilms, sediments, and microbial mats. Mol. 780 Microb. Ecol. Man. 2008, 2, 3483-3514.

(26) Terada, A.; Lackner, S.; Tsuneda, S.; Smets, B. F. Redox- 782 stratification controlled biofilm (ReSCoBi) for completely autotrophic 783 nitrogen removal: the effect of co- versus counter-diffusion on reactor 784 performance. Biotechnol. Bioeng. 2007, 97 (1), 40-51.

785

(27) Reichert, P. AQUASIM 2.0-Computer program for the 786 identification and simulation of aquatic systems; EAWAG: Dubendorf, 787 Switzerland, 1998.

(28) Hiatt, W. C.; Grady, C. P. L. An updated process model for 789 carbon oxidation, nitrification, and denitrification. Water Environ. Res. 790 2008, 80, 2145-2156.

(29) Hellinga, C.; Van Loosdrecht, M. C. M.; Heijnen, J. J. Model 792 Based Design of a Novel Process for Nitrogen Removal from 793 Concentrated Flows. Mathematical and Computer Modelling of 794 Dynamical Systems 1999, 5, 351-371.

(30) Blackburne, R.; Yuan, Z.; Keller, J. Demonstration of nitrogen 796 removal via nitrite in a sequencing batch reactor treating domestic 797 wastewater. Water Res. 2008, 42, 2166-2176.

(31) Sötemann, S.; Musvoto, E.; Wentzel, M.; Ekama, G. Integrated 799 biological, chemical and physical processes kinetic modelling Part $1-800$ Anoxic-aerobic $\mathrm{C}$ and $\mathrm{N}$ removal in the activated sludge system. Water 801 SA 2006, 31 (4), 1044-1062.

802

(32) Van Hulle, S. W. H.; Volcke, E. I. P.; Teruel, J. L.; Donckels, B.; 803 van Loosdrecht, M. C. M.; Vanrolleghem, P. A. Influence of 804 temperature and $\mathrm{pH}$ on the kinetics of the Sharon nitritation process. 805 J. Chem. Technol. Biotechnol. 2007, 82 (5), 471-480.

(33) Musvoto, E. V.; Wentzel, M. C.; Loewenthal, R. E.; Ekama, G. 807 A. Integrated chemical-physical processes modelling - I. Development 808 of a kinetic-based model for mixed weak acid/base systems. Water Res. 809 2000, 34 (6), 1857-1867.

810

(34) Hao, X.; Heijnen, J. J.; Van Loosdrecht, M. C. Model-based 811 evaluation of temperature and inflow variations on a partial 812 nitrification-ANAMMOX biofilm process. Water Res. 2002, 36 (19), 813 4839-4849.

(35) Wang, R.; Terada, A.; Lackner, S.; Smets, B. F.; Henze, M.; Xia, 815 S.; Zhao, J. Nitritation performance and biofilm development of co- 816 and counter-diffusion biofilm reactors: modeling and experimental 817 comparison. Water Res. 2009, 43 (10), 2699-2709.

818

(36) Pellicer-Nàcher, C.; Domingo-Félez, C.; Lackner, S.; Smets, B. 819 F. Microbial activity catalyzes oxygen transfer in membrane-aerated 820 nitritating biofilm reactors. J. Membr. Sci. 2013, 446, 465-471.

(37) Power, M. The predictive validation of ecological and 822 environmental models. Ecol. Modell. 1993, 68 (1-2), 33-50. 823

(38) Brockmann, D.; Rosenwinkel, K.-H.; Morgenroth, E. Practical 824 identifiability of biokinetic parameters of a model describing two-step 825 nitrification in biofilms. Biotechnol. Bioeng. 2008, 101 (3), 497-514. 826

(39) Lackner, S.; Smets, B. F. Effect of the kinetics of ammonium and 827 nitrite oxidation on nitritation success or failure for different biofilm 828 reactor geometries. Biochem. Eng. J. 2012, 69, 123-129.

829

(40) Vangsgaard, A. K.; Mauricio-Iglesias, M.; Valverde-Pérez, B.; 830 Gernaey, K. V.; Sin, G. pH variation and influence in an autotrophic 831 
832 nitrogen removing biofilm system using an efficient numerical solution 833 strategy. Water Sci. Technol. 2013, 67 (11), 2608.

834 (41) Wyffels, S.; Van Hulle, S. W. H.; Boeckx, P.; Volcke, E. I. P.; Van 835 Cleemput, O.; Vanrolleghem, P. A.; Verstraete, W. Modeling and 836 simulation of oxygen-limited partial nitritation in a membrane-assisted 837 bioreactor (MBR). Biotechnol. Bioeng. 2004, 86 (5), 531-542.

838 (42) Volcke, E. I. P.; Sanchez, O.; Steyer, J.-P.; Dabert, P.; Bernet, N. 839 Microbial population dynamics in nitrifying reactors: Experimental 840 evidence explained by a simple model including interspecies 841 competition. Process Biochem. 2008, 43 (12), 1398-1406.

842 (43) Chung, J.; Bae, W.; Lee, Y.-W.; Rittmann, B. E. Shortcut 843 biological nitrogen removal in hybrid biofilm/suspended growth 844 reactors. Process Biochem. 2007, 42 (3), 320-328.

845 (44) Brockmann, D.; Morgenroth, E. Evaluating operating conditions 846 for outcompeting nitrite oxidizers and maintaining partial nitrification 847 in biofilm systems using biofilm modeling and Monte Carlo filtering. 848 Water Res. 2010, 44 (6), 1995-2009.

849 (45) Yoo, H.; Ahn, K.-H.; Lee, H.-J.; Lee, K.-H.; Kwak, Y.-J.; Song, 850 K.-G. Nitrogen removal from synthetic wastewater by simultaneous 851 nitrification and denitrification (SND) via nitrite in an intermittently852 aerated reactor. Water Res. 1999, 33 (1), 145-154.

853 (46) Gilbert, E. M.; Agrawal, S.; Brunner, F.; Schwartz, T.; Horn, H.; 854 Lackner, S. Response of Different Nitrospira Species To Anoxic 855 Periods Depends on Operational DO. Environ. Sci. Technol. 2014, 48 856 (5), 2934-2941.

857 (47) Kornaros, M.; Dokianakis, S. N.; Lyberatos, G. Partial 858 Nitrification/Denitrification Can Be Attributed to the Slow Response 859 of Nitrite Oxidizing Bacteria to Periodic Anoxic Disturbances. Environ. 860 Sci. Technol. 2010, 44 (19), 7245-7253.

861 (48) Gilbert, E. M.; Agrawal, S.; Brunner, F.; Schwartz, T.; Horn, H.; 862 Lackner, S. Response of Different Nitrospira Species To Anoxic 863 Periods Depends on Operational DO. Environ. Sci. Technol. 2014, 48 864 (5), 2934-2941.

865 (49) Li, J.; Elliott, D.; Nielsen, M.; Healy, M. G.; Zhan, X. Long-term 866 partial nitrification in an intermittently aerated sequencing batch 867 reactor (SBR) treating ammonium-rich wastewater under controlled 868 oxygen-limited conditions. Biochem. Eng. J. 2011, 55 (3), 215-222.

869 (50) Mota, C.; Head, M. A.; Ridenoure, J. A.; Cheng, J. J.; de los 870 Reyes, F. L. Effects of Aeration Cycles on Nitrifying Bacterial 871 Populations and Nitrogen Removal in Intermittently Aerated Reactors. 872 Appl. Environ. Microbiol. 2005, 71 (12), 8565-8572.

873 (51) Kornaros, M.; Marazioti, C.; Lyberatos, G. A pilot scale study of 874 a sequencing batch reactor treating municipal wastewater operated via 875 the UP-PND process. Water Sci. Technol. 2008, 58 (2), 435-438. 